\title{
The Impact of Customer Value Management on Potential Profits - A Proposed Management Accounting Framework
}

\author{
Abeer Mohamed \\ Bryant University, Bitzh \\ E-mail: abeer.mohamed@ zhuhai.bryant.edu
}

Received: January 19, 2020

Accepted: February 12, 2020

Published: March 17, 2020

doi:10.5296/ijafr.v10i1.16279

URL: https://doi.org/10.5296/ijafr.v10i1.16279

\begin{abstract}
Purpose- The purpose of this study is to propose a customer value management framework to improve the potential profits using the Management accounting techniques.

Design/methodology/approach- Based on the literature, this study identifies and adapts the most appropriate management accounting techniques to manage the customer value and hence improve potential profits. It also tests the perceptions of managers and management accountants of the Egyptian service sector concerning the relative merits of such a framework.

Findings- The most significant finding is that the current study accepted the revised model because it provided better fit indices compared with the fit indices of the hypothesized model. A key finding in the current study that has not been investigated in previous studies is that the customer value analysis has a positive and significant impact on companies' profitability. The study also found that there is an indirect relationship between customer profitability analysis and companies' profitability. Other factors in the proposed framework have significant positive relationships.

Originality/value- This paper contributes to management accounting literature by proposing a framework for managing customer value for the potential profits improvement purpose, using customer profitability analysis; customer value analysis; and value add-costing techniques together with the proposed sequences. It is also a practical contribution to improving the potential profits of the Egyptian service sector.
\end{abstract}

Keywords: Customer profitability analysis, Customer value analysis, Value add-costing, Companies' profitability, Egyptian service sector 


\section{Research Context}

Measuring and Managing Customer value can only come from building the customer into every aspect of operations. Information about the customer value makes it possible for the company to identify more profitable customers and make decisions about improving, canceling, or adding a certain activity and about the management of those activities that cause customer profitability. This results in improving the company's overall profitability. This requires building a comprehensive view of customer value management.

Over the past decade, management accounting research has been focused on using single different management accounting techniques that reflect customer value. However, despite an increasing amount of management accounting literatures which focus on customer value, most of which is single technique oriented such as the studies of Cooper and Kaplan (1991); Smith and Dikolli (1995); Pickering Mark (1998); McNair et al. (2001); Salem (2002); Morse, Davis and Harlgraves (2003); McNair, et al. (2006); McNair, et al. (2005); Raaij (2006); Raaij (2007); Horngren, et al.(2005); and Gary Cokins (2015), there remains a lack of holistic view in customer value and how this can be effectively managed and enhance companies' profitability.

The purpose of this paper is to develop a customer value management framework to improve companies' profitability using Management accounting techniques.

This framework consists of three steps. First, adopt customer profitability analysis technique to provide companies with information about the profitability of each customer. Next, use a customer value approach to better understanding of which activities and outcomes actually create value for profitable customers. The last step is to use customer value costing technique to manage the relationship between the value and cost of achieving such value and make the customer value the effective force in achieving profitability. Taken together the three techniques with the proposed sequences form a framework that provides deeper insight into managing customer value and boosting companies' profitability from the management accounting perspective.

This paper explores the development of such a comprehensive management accounting framework to assist in managing customer value and enhance the company's profitability. No previous research in this subject area has combined these three techniques. This exploratory research adds new knowledge in the field through theoretical development. The lack of management accounting literature that concerns a comprehensive view in managing customer value including the three techniques supports the need for this study.

\section{The Development of a Proposed Framework for Customer Value Management}

\subsection{Customer Profitability Analysis}

To remain competitive, companies must acquire more profitable customers as companies shift from a product-centric focus to a customer-centric focus, a myth that almost all current customers are profitable needs to be replaced with the truth. Some high demanding customers may indeed be unprofitable, many companies' managerial accounting systems aren't able to 
report customer profitability information to support analysis for how to rationalize which types of customers to retain, grow (Gary Cokins, 2015). This is previously supported by the notion that 80 percent of a company's profits come from 20 percent of its customers, while the remaining 20 percent of profits are provided by 80 percent of customers (Zeithamlet et al., 2001; Horngren et al., 2006 and Reinaldo et al., 2008). Companies that understand which customers are more profitable and which ones are not being armed with valuable information needed to make successful managerial decisions to improve overall organizational profitability (Howell, Robert, and Soucy, 1990; Raaijet et al., 2003; Cotton, 2005; Ilhan Dalci et al., 2008). Consequently, this study proposes the use of customer profitability analysis technique-based on $\mathrm{ABC}$ approach as the first step in the proposed framework. This technique enables companies to identify the profitability of customers based on the specific resources used to service each customer (Pickering, 1998). Raaij (2005) defines "Customer profitability analysis as the process of allocating revenues and costs to customer segments or individual customer accounts, such that the profitability of those segments and/or accounts can be calculated.

The following package of steps for performing customer profitability analysis is adapted from the studies of (Cooper and Kaplan, 1991; Smith and Dikolli, 1995; Pickering Mark 1998; Salem, 2002; Morse, Davis, and Harlgraves, 2003; Raaij, 2005; Horngren et al., 2005; and Gary Cokins, 2015). Firstly, determining the customers who dealt with the company within a certain period of time. Secondly, classifying customers according to distribution areas, average demand value, or the volume of their purchases. Thirdly, determining the revenues of each customer, or group of customers, according to the selected classification, by tracing as many revenue items as possible. Fourthly, determining customer costs, by using an activity cost approach as follows:

- Categorizing cost related to customers into different cost pools by using a customer cost hierarchy (Customer output-unit-level costs; Customer batch-level costs; Customer-sustaining costs; Corporate-sustaining costs and Distribution-channel costs)

- Specifying and classifying customer activities. There is no specific classification for customer activities the classification of customer activities differ according to the type of product and services and the nature of each industry or service

- Determining the activities in each cost-hierarchy and identifying the total costs of every activity by defining the cost drivers for each activity at the individual customer level or the customer group level and Cost drivers units for each activity. The cost allocation rate is calculated by dividing the total activity costs by the total of cost drivers units.

- Identifying the total activity costs for each customer by multiplied cost drivers units for each activity by allocation rate. Then, the total costs for customer activities are calculated at the level of each customer.

Finally, determining customer-level operating profit. Companies should use a report that illustrates the difference between the revenues generated from each customer and the total costs in order to compute a customer profitability figure. Customers are rank ordered from 
the most profitable to the least profitable, including those who are unprofitable (i.e., customers with a financial loss where their costs exceed their revenues. This enables the company to make decisions about the appropriate strategy for each group of customers.

Companies should focus on profitable customers because these customers will contribute to enhancing the profitability of the company.

\subsection{Customer Value Analysis}

In order to focus on profitable customers, the current study proposes the use of customer value analysis as the second step in the proposed framework. This is further supported by McNair et al.'s (2001a) study which states that understanding customers and value performance is the first step in cost management practices that lead to profitability and long-term growth.

Customer value is a strategic weapon in attracting and retaining customers and has become one of the most significant factors in the success of both manufacturing businesses and service providers (Gale, 1994; Woodruff, 1997; and Zeithaml et al., 2001). Delivering superior customer value has become an ongoing concern in building and sustaining competitive advantage. As many researchers have suggested, firms should reorient their operations towards the creation and delivery of superior customer value (Jensen, 2001; and Day, 1994). Delivering superior customer value is now recognized as one of the most important factors for the success of any firm now and in the future.

Woodruff (1997) defined customer value as a customer-perceived preference for, and evaluation of, product attributes, attribute performances, and consequences in terms of the customer's goals and purposes. Thus, the customer value perspective begins by gaining a better understanding of which activities and outcomes actually create value for the customers. It also entails knowing the resources that are consumed to meet specific customer needs (McNair; et al., 2006).

Thus the current study proposes the use of customer value analysis as a second step in the proposed framework.

Customer Value Analysis begins with a deep understanding of firm's value proposition- the list of attributes that have the potential to create customer value-and how effectively that value proposition maps to a customer's value profile for the product or service (McNair et al., 2006). Product attributes embody those characteristics, features, and benefits desired by, and that create value for the customer and which the organization will need to provide competitively in order to generate revenue. A clear understanding of product attributes by the organization facilitates decision making about resources and capabilities required to meet customer needs and are antecedent to the determination of the costs of creating value for each customer and consideration of profit.

In order to analyze customer value, the following steps are followed (Gabre, 2007): Firstly, identifying attributes for each alternative of product: a customer regards the product as a set of attributes that offer a benefit or a number of benefits that satisfy needs. Customer value 
attribute data are collected by a survey of an unbiased sample of customers. This survey asking a number of customers about the main attribute they wish to have available in the product. This can be done by telephone or by mail. Secondly, determining the availability of the attribute in each product from the customer's viewpoint: In this context, different weights can be used, ranging from 1 to 5. The use of percentages to represent the availability of the attribute in each alternative could also be used. Thirdly, determining the degree of importance given by the customer to each attribute: here also the previous weights can be used. It is also possible to use percentages that represent, in total, the figure 1 as a whole number. Finally, determining the expected value of each alternative: in this step, it is possible to estimate the degree of importance given by the customer for each attribute value obtained by the customer from each alternative. The value obtained by the customer from each alternative could be calculated by adding "the degree of availability of each attribute of the individual value" to degree of importance determined by the customer for each attribute. The alternative that achieves the highest expected customer value can be chosen

\subsection{Value-Added-Costing}

To generate this customer value, Al-Nashar (2001) states that it is necessary, therefore, to manage the relationship between the value and cost of achieving such value, and to make the customer value the effective force in the companies' continuity and in achieving profitability. However, Al-Nashar illustrates that under the traditional management accounting system, there is no link between the cost and the value it achieves, which is one of the most important requirements for distinguished business companies at the international level. This is further supported by the study conducted by McNair et al. (2006), which affirmed that understanding the relationship between costs and the value provided by the company to the customer is the basis for the company's ability to achieve profits. Therefore, the cost structure should be associated with the value attributes of the product or the service. McNair et al. (2013) emphasized that the only way to increase profits is to better understand the target and meet the value requirements defined by the firm's customers. A company that does not understand which of its activities tie directly to defined customer value attributes is likely to face lower profits and an uncertain future. At the present time, success does not result from reducing cost but rather from increasing value. Therefore companies should focus on the core value activities and related cost.

This goal can be recognized by adopting the value- added costing as a third step in the proposed framework.

This proposed technique is based on two stages. The first stage is to identify activities related to each attribute (Brimson, 1998). At this stage, the "activity analysis" technique is used to provide detailed data for a company's operating level. The activities data are collected by interviewing the appropriate department manager. This helps to better understand the activities, how they should be performed, managed and improved, and to what extent they can be changed to be appropriate to the market and competition conditions. This activity analysis classifies the activities into three types of activities.

Firstly, waste activities represent cost which is not customer-related, and for which the 
customer will not pay any money. Therefore, such activities are profit-consuming. Waste is sometimes referred to as a "profit bandit" (McNair et al., 2001b, 2006 and 2013). Waste represented by two elements: redoing the activity which can be value-adding when done for the first time, but they are non-value-adding when they are done again.in addition to the excess in doing activities, to the extent that they cost higher than what the customer would pay. This creates further waste.

Secondly, non- value-adding activities: These are classified into three types. Current value-adding business activities: these are a group of activities that are necessary for supporting value-adding activities. The customer will not pay a higher price for performing such activities efficiently (i.e. they have no effect on profit). However, the customer may pay a lower price if such activities are not performed efficiently (this will have a negative effect on profit). In addition, future value-adding business activities: these are represented in the future products and services of the company, such as innovation and development. The customer will not pay a price for future products and services (i.e. they have no effect on profit). However, the company is obliged to do so for survival and growth.

Finally, Administrative value-adding business activities: these are the main activities that are necessary for the continuity of work, such as salaries and information technology. The customer will not pay a price for the performance of such activities, and therefore they have no effect on profit. Thirdly, the core of value-adding activities is represented by those activities that realize direct benefit for the customer because they are strongly linked to value attributes. That is, they are determined on the basis of the product's attributes. Only such activities can generate revenues for the company. The value-added core is only a small percentage of the total price for a product or service. On average, the value-added core is only $20 \%$ of the price. In other words, Pareto's law seems to hold: $20 \%$ of the activities generate 80 to $90 \%$ of the firm's revenue. This suggests the first "new law" of cost management under value perspective: price is a multiplicative function of the value-added core of activities. Therefore, they must be regarded as a profit driver that must be focused on. There is a direct proportion between such activities and profit; each monetary unit spent on improving such activities is a means of improving profit. In other words, the companies that cannot determine which activities are directly related to value attributes are companies that have an uncertain future.

The second stage is to Identify the cost of each activity and measuring the costs of each attribute. Activity cost is represented by the proportion of each activity of production factors consumed by the activity and recorded as cost in the general ledger. Therefore, at this stage, production factors that are necessary for the performance of each activity and represented in personnel, equipment, materials, etc., are identified and grouped (Brimson, 1998). They are calculated on the basis of actual performance. In this step the use of the normal ABC approach to cost of the product attributes is suggested, that is, using cost drivers and cost rates. These calculations are straightforward where there is a direct one to one relationship between each activity and a particular product attribute. Some apportionment may be necessary where two or more activities are required to deliver a particular attribute, or one activity delivers two or more product attributes. Finally, the activity costs related to each 
attribute are grouped together (Walker, 1992, 1998 \&1999, Brimson, 1998, and Abeer 2017).

It can be concluded that the proposed framework consists of three steps. First, adopt customer profitability analysis technique to provide companies with information about the profitability of each customer. Next, use a customer value approach to better understanding of which activities and outcomes actually create value for profitable customers. The last step is to use customer value costing technique to manage the relationship between the value and cost of achieving such value and make the customer value the effective force in achieving profitability. The following figure illustrates the proposed framework and its variables.

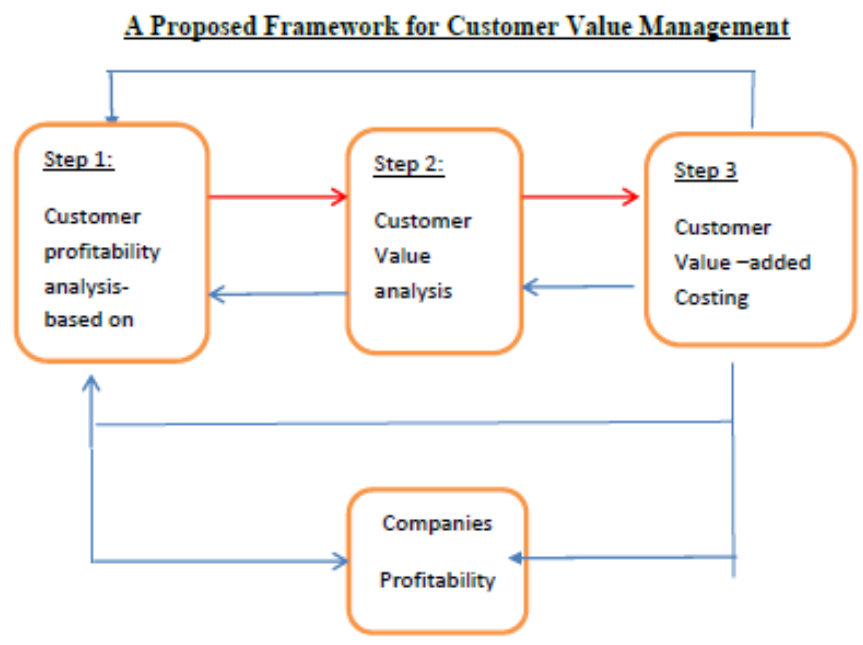

Figure 1. Customer value management framework

The proposed framework hypotheses can be formulated as follows:

H1: Customer profitability analysis is positively affected by companies' profitability.

$\mathrm{H} 2$ : Customer value-added is positively related to Customer profitability.

H3: Value-added costing is positively related to Customer value-added.

H4: Value-added costing is positively affecting companies' profitability.

H5: Value-added costing is positively affecting Customer profitability analysis.

\section{Approach to Test the Model}

\subsection{Population and Sample}

The service sector is becoming increasingly important in the economies of developed and developing countries. Egypt's economy is the second largest in the Arab world (after Saudi Arabia). The service sector is the largest and fastest-growing economic sector and accounts for almost 51 percent of GDP (Anonymous a., 2018). In addition to the importance of the service sector, this sector is the most appropriate to examine the proposed framework since the customer is the main focus in the proposed framework and in the service sector (ECS). This is affirmed by Kaplan and Narayanan (2001) who state that understanding customer value is especially important for service customer. Indeed, for service companies, customer 
value is more important than production companies because the cost of providing a service is generally determined by customer behavior. According to Zeithaml and Bitner (1996), the cost of finding and gaining a new customer in service companies is five times greater than the cost of retaining current customers. Therefore, successful implementation of customer value management in order to retain profitable relationships with current customers is essential for service companies. Moreover, Cotton (2005) asserts that the effective use of CPA enables service companies to increase customer satisfaction and boost profitability.

Due to time and resource restrictions, a judgment sample is used in the current study. The study focuses only on the service sector's companies which listed in the Egyptian Exchange Market. The sample is drawn from the Egyptian Exchange Market database. The sample included all members of service sectors who listed in EEM. The sample frame was 74 service companies (the total membership of EEM at the time) (Anonymous b, 2018). This sample consists of 35 Financial services companies; 15 Banks; 4 Telecommunication companies; 4 Technology companies and16 Travel and leisure companies (Anonymous b, 2018).

The respondents were management accountants, production managers, sales managers, financial and accounting manager- marketing manager and customer service manager because they are able to comment accurately on the aspects in the questionnaire since they have expertise in decision-making at the strategic level.

\subsection{Questionnaire Development}

A questionnaire was used to collect the data. A self-administrated questionnaire, delivered and collected by hand, was utilized to test the proposed framework. This framework was used to develop the questionnaire to test the proposed framework. The objective of this questionnaire was to collect data about the perception of managers and management accounts related to each variable in the framework and their relationships, which can then be used in evaluating the developed customer value management framework. To achieve this objective, the questionnaire was divided into four main sections (Customer profitability analysis; Customer value analysis; Customer value-added costing and the impact of the proposed framework on companies' profitability).

Care was taken to ensure that questions covered all theoretical constructs contained in the proposed framework. In addition, a 5-point Liker-type scale (from (1) not important to (5) very important for some questions and from (1) completely disagree to (5) completely agree with others) was used in most questions. In this research, closed question format was deemed the most appropriate type due to the pressure of respondents' time and a cultural dislike of such open questions, as they require a detailed answer, closed questions were deemed to be most appropriate.

The questionnaire was pre-tested and evaluated by 5 reviewers, two academics familiar with the service sector, one academic statistician specializing in accounting research and three practitioners. Reviewers were asked to test the questionnaire and identify unclear items and suggest changes. Changes were made, based on the comments and suggestions received from the reviewers. 


\subsection{Response Rate Strategies}

Questionnaires were distributed by hand to 370 individuals (74 companies). After one week, companies which had not replied within the first week were contacted by phone as a reminder. After four weeks a reminder letter with another copy of the questionnaire was delivered by hand to companies which had not replied. 170 individuals apologized for not completing the questionnaire. Of the completed questionnaires, 99 were completed and collected after the first delivery. 40 were collected after the first follow-up process. A further 60 were collected after the second follow-up process. A total of 199 completed questionnaires were received.

\subsection{Response Bias}

Once all questionnaires were returned a test was conducted to ensure that there was no significant difference between the responses received in the early and late stages of data collection. To enact this, the first and last 60 questionnaires were compared. The figure of 60 was used based on the slightly smaller number of a questionnaire received in the second phase and to ensure an equal sample size for comparison. The testing was done through the application of the two-sample Kolmogorov-Smirnov test. The test showed that of the 100 variables there was no significant difference.

\section{Findings and Discussion}

\subsection{Factor Analysis for the Variables of the Proposed Framework}

Structural factor analysis was applied for variables of the proposed framework (customer profitability analysis; Customer value-added and value-added costing) to examine the underlying relationships between variables. Common factor analysis with principal component was used.

For the customer profitability analysis. Seven items from 15 included in the analysis have communality values ranging from 0.4 to 0.7 (from lower to moderate), which are common magnitudes in social science (Velicer and Fava, 1998). Eight items have communality values above 0.7 , which represent high commonality. In addition, most of the items have a factor loading above 0.49 . Furthermore, all items are loaded highly on only one factor and are not split-loaded. The principal component provided a five-factor solution with eigenvalues of 1.0 or above, and 15 items are retained under the five factors which explain 60 percent of the variance in the data set. The first factor accounts for 20 percent of the variance, the second for 16 percent, the third for 14 percent, and the fourth for 5 percent and the fifth for 5 percent.

For reliability analysis, Cronbach's alpha is calculated to test reliability and internal consistency for each factor. The result indicates that the alpha coefficient for all factors is above 86 percent, which is higher than the standard estimates of 0.70 (Howitt and Cramer, 2008). In addition, the Spearman's intercorrelation for the five factors is significant at the 0.001 level.

The factors are labeled according to the commonality of items loading on each factor and they are labeled as follows: determining customers who dealt with the company; classifying customers; determining the revenue of each customer; determining customer costs and 
determining customer operating profit.

For customer value analysis variable. Among the 11 items included in the analysis, 4 have communality values ranging from 0.4 to 0.7 (from lower to moderate), which are common magnitudes in social science (Velicer and Fava, 1998). 7 items have a factor loading greater than 0.69, indicating a strong correlation between items and the factor they belong to. Furthermore, all items are loaded highly on only one factor and are not split-loaded on another factor above 0.32 (Tabachnick and Fidell, 2001). The principal component provides a four-factor solution with eigenvalues of 1.0 or above being extracted, and the 11 items which are retained under the four factors explain 61 percent of the variance in the data set. The first factor accounts for 20 percent of the variance, the second for 18 percent, the third for 18 percent and the fourth for 5 percent. None of the remaining factors is significant.

For reliability analysis, Cronbach's alpha is calculated to test reliability and internal consistency for each factor. The result indicates that the alpha coefficient for all factors is above 86 percent, which is higher than the standard estimates of 0.70 (Howitt and Cramer, 2008). In addition, the Spearman inter-correlation for the four factors is significant at the 0.001 level.

The factors are labeled according to the commonality of items loading on each factor and are as follows: Identifying attributes for each alternative of product, determining the availability of the attribute in each product from the customer's viewpoint, determining the degree of importance given by customer to each attribute and determining the expected value of each alternative.

For the value-added costing variable. Among the 12 items included in the analysis, 5 have Communality values ranging from 0.4 to 0.7 (from lower to moderate), which are common magnitudes in social science (Velicer and Fava, 1998). In addition, 10 items have a factor loading greater than 0.69 , indicating a strong correlation between items and the factor they belong to. Furthermore, all items are loaded highly on only one factor and are not split-loaded on another factor above 0.32 (Tabachnick and Fidell, 2001). The principal component provides a two-factor solution with eigenvalues of 1.0 or above being extracted, and the 15 items which are retained under the two factors explain 61 percent of the variance in the data set. The first factor accounts for 34 percent of the variance, the second for 27 percent. None of the remaining factors is significant.

For reliability analysis, Cronbach's alpha is calculated to test reliability and internal consistency for each factor. The result indicates that the alpha coefficient for all factors is above 87 percent, which is higher than the standard estimates of 0.70 (Howitt and Cramer, 2008). In addition, the Spearman intercorrelation for the two factors is significant at the 0.001 level.

The factors are labeled as follows: Identify activities related to each attribute and identify the cost of each activity and measure the cost of each attribute. 


\subsection{Testing Hypotheses}

The assumptions of multivariate normality were first evaluated using the Shapiro-Wilk Test because the sample size is less than 200 (see table1). The Test indicated that CPA; CVA; VAC and $\mathrm{CP}$ were normally distributed because the value of the Shapiro-Wilk Test is greater than 0.05. The model was tested using AMOS 24. The maximum likelihood parameter estimation was adopted over other estimation methods (weighted least squares, two-stage least squares, asymptotically distribution-free $[\mathrm{ADF}]$ ) because the data were distributed normally (Kline, 2005).

The hypothesized theoretical model was first tested and then revised the model based on constraining parameters with small t-statistics or relaxing parameters with large modification indices in order to build a model that better fits the empirical data. While constraining parameter enables detection of potential errors of commission (i.e. including unnecessary relationships), relaxing parameter reveals errors of omission (i.e. excluding relationships that might have theoretical and practical significance) (Keith, 2006). Nonetheless, the revision of the model has to make theoretical sense (Hair et al., 2006).

\subsubsection{Hypothesized Model}

To test the conceptual framework in figure 1, first, the overall model and the strength of the direct and indirect effects among variables were explored and then revised the hypothesized model by constraining parameters with small t-statistics or relaxing parameters with large modification indices. The results of the conceptual model corresponding to figure 1 was reported in figure 2 and table 2. Various recommendations have been proposed for fit indices. A model is considered to have a good model-data fit if the ratio of $\mathrm{x} 2$ to degree of freedom ( $\mathrm{x}$ $2 / \mathrm{df}$ ) is less than 3, the RMSEA is less than 0.08, the root mean square residual (RMR) is below 0.10, the comparative fit index (CFI) and goodness-of-fit index (GFI) are above 0.90, the adjusted goodness-of-fit index (AGFI) is above 0.80 and the closer the value of normed fit index (NFI) to 1, the better the fit (Byrne, 1998; Chin and Todd, 1995; Hu and Bentler, 1995).

The fit indices of the Conceptual model were found to be partially satisfactory. Although most of the indices are in line with recommended benchmarks (CFI .995, NFI .993; TLI .970; and RMR .004), the indices (ratio of $x 2$ to the degree of freedom (x 2/df) 3.642, RMSEA .116) are not in line with the recommended benchmarks (see table 2). Therefore the fit indices of the structural model showed a partially acceptable fit with the dataset.

On the other hand, the structural path relationships and corresponding coefficients (see table 2) reveal that Customer profitability analysis has a significant positive influence on companies' profitability (b .691; p 0.001). Table 2 also shows that Customer value-added is positively associated with Customer profitability (b .801; p 0.001). Furthermore, Value-added costing is positively associated with Customer value-added (b .568; p 0.001). Moreover, the analysis shows that Value-added costing has a significant positive influence on companies' profitability. Finally, Value-added costing also has a significant positive influence on Customer profitability analysis. This means that the results of the structural path relationships 
and corresponding coefficients fully support all hypotheses.

Table 1 . Tests of normality

\begin{tabular}{lllllll}
\hline & \multicolumn{4}{l}{ Kolmogorov-Smirnova } & \multicolumn{4}{l}{ Shapiro-Wilk } \\
\cline { 2 - 7 } & Statistic & df & Sig. & Statistic & df & Sig. \\
\hline CPA & .044 & 199 & $.200^{*}$ & .996 & 199 & .832 \\
\hline CVA & .090 & 199 & .060 & .992 & 199 & .299 \\
\hline VAC & .062 & 199 & .062 & .991 & 199 & .214 \\
\hline CP & .155 & 199 & $200^{*}$ & .953 & 199 & .721 \\
\hline
\end{tabular}

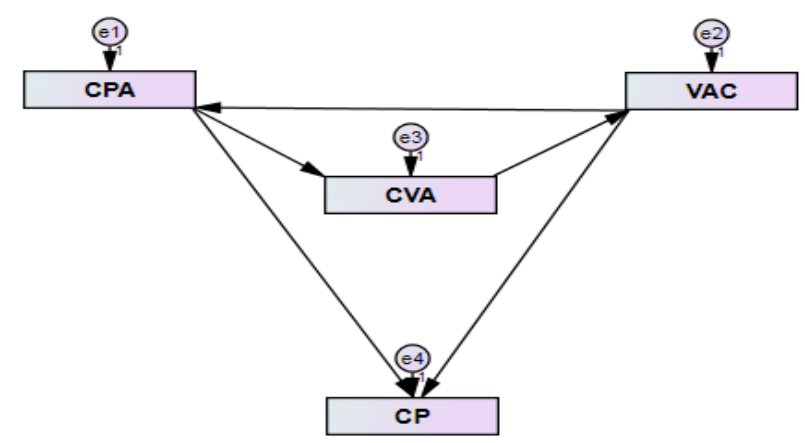

Figure 2. Hypothesized model

Table 2

\begin{tabular}{lllllll}
\hline $\begin{array}{l}\text { Dependent } \\
\text { variable }\end{array}$ & Independent variable & Hypothesis & of & B & $\mathrm{p}$ & Conclusion \\
\hline \multicolumn{7}{c}{ hypothesis } \\
\hline $\mathrm{CP}$ & $\mathrm{CPA}$ & $\mathrm{H} 1$ & Positive & .691 & $<0.001$ & Significant \\
\hline $\mathrm{CVA}$ & $\mathrm{CPA}$ & $\mathrm{H} 2$ & Positive & .801 & $<0.001$ & Significant \\
\hline $\mathrm{VAC}$ & $\mathrm{CVA}$ & $\mathrm{H} 3$ & Positive & .568 & $<0.001$ & Significant \\
\hline $\mathrm{CP}$ & $\mathrm{VAC}$ & $\mathrm{H} 4$ & Positive & .411 & $<0.001$ & Significant \\
\hline
\end{tabular}




$\begin{array}{lllllll}\text { CPA } & \text { VAC } & \text { H5 } & \text { Positive } & .718 & <0.001 & \text { Significant }\end{array}$

\section{Research}

Recommended level of

Fit index fit model

\begin{tabular}{lll}
\hline x2/df & $\begin{array}{l}\text { Ratio of } \chi \text { to df } \leq 2 \\
\text { or 3, useful for nested } \\
\text { models/model }\end{array}$ & 3.642 \\
\hline RMSEA & $\leq .08$ & .116 \\
\hline RMR & $\begin{array}{l}\text { below 0.10, the better; } \\
\text { 0 indicates perfect fit }\end{array}$ & .004 \\
\hline CFI & $>.90$ for acceptance & .995 \\
\hline GFI & $>.90$ for acceptance & .991 \\
\hline AGFI & $>.80$ \\
\hline NFI & $\begin{array}{l}\text { Closer to } 1, \text { the better } \\
\text { the fit }\end{array}$ & .993 \\
\hline TLI & $\begin{array}{l}\geq .95 \text { can be } 0<\text { TLI }<1 \\
\text { for acceptance }\end{array}$ & .970 \\
\hline IFI & $\geq .95$ for acceptance & .995 \\
\hline
\end{tabular}

\subsubsection{Revised Model}

While the initial model appears partially acceptable fit with the dataset, all paths are significant. The model was revised to improve the fit indices by removing the path one (CP $<--\mathrm{CPA})$ and add a new path (CP <---CVA). This revised model is the best model. Table 3 reported the results of the revised model shown in Figure 3. The revised model appears to fit the data well. All of the indices are in line with recommended benchmarks (Byrne, 1998; Chin and Todd, 1995; Hu and Bentler, 1995) for an acceptable fit.

The fit indices of the revised model are compared with those of the hypothesized model. The fit indices of the revised model were found to be satisfactory (x2/df 1.750; RMSEA .062; 
CFI .999; TLI .991; NFI .997; and RMR .004). The revised model has a smaller (x2/df) and RMSEA which within the acceptance range. In addition, the various fit indexes appeared to favor the revised model. It can be concluded that the revised model provided a better fit compared with the fit indices of the hypothesized model. Thus, the revised model is accepted as it is a more parsimonious model (Hair et al., 2006; Keith, 2006). Table 3 indicates that all paths coefficients in the revised model are significant.

Significant results of this study suggest that there are positive significant relationships between Customer value-added and Customer profitability; Value-added costing and Customer value-added; Value-added costing and companies' profitability; and Value-added costing and Customer profitability analysis. Therefore, the hypotheses (H2, H3, H4, and H5) can be accepted. A key finding of the revised model reveals that there is no direct relationship between customer profitability analysis and companies' profitability.

In the revised model, we further examined the relationship between customer value analysis and companies profitability which is a new path in the revised model. The direct effect (of customer value analysis on companies' profitability) and the indirect effect (of customer profitability analysis on companies' profitability) were also examined (see table 4).

Although the path from customer profitability analysis to the companies' profitability was removed from the revised model, the result indices that there is an indirect effect of the customer profitability analysis on the companies' profitability. Further, the correlation analysis was run to test the association between the customer profitability analysis and the companies' profitability and between the customer value analysis and companies profitability (the new relationships in the revised model). The result of this test indicates that a statistically significant correlation at .001 level exists between the customer profitability analysis and companies' profitability, with a moderate correlation coefficient of .580 (Hair et al., 2007). This test also indicates that a statistically significant correlation at .001 level exists between the customer value analysis and companies' profitability, with a high correlation coefficient of .788 (Hair et al., 2007). This means that the findings of the path model result consistent with the findings of correlation analysis.

This empirical evidence in regards to the relationship between customer value analysis and profitability are also supported by Studies of Sullivan et al. (2012); Tymoteusz \& Przemysław (2016) and Valenzuela \& Torres (2017); in that the application of customer value management would have a positive influence on the financial results of the company. This finding is further supported by Gale (2000) who indicated that companies that use the customer value approach achieved a return on sales greater than other companies. This is further confirmed by Howes (2003) who noted that the application of this approach is expected to increase companies' profitability at a rate of about $10 \%$ per annum. Moreover, Brewton and Schiemann (2003) suggested that the variations between financial performances are due to the difference in mechanisms for managing customer value. This means that customer value is a critical approach for generating profitability (McNair et al. 2001 and Cokins, 2006). This emphasizes that the literature review has consistent evidence with regards to the significant relationship between customer value analysis and profitability. 


\section{Mll Macrothink}

International Journal of Accounting and Financial Reporting ISSN 2162-3082 2020, Vol. 10, No. 1

However, developing a comprehensive framework to manage customer value has not addressed in these studies.

One of the significant findings of the revised model is that the use of customer value analysis moderates the relationship between customer profitability analysis and companies profitability. This also supported by the other result which indicates that there is an indirect effect of the customer profitability analysis on the companies' profitability. This finding is supported by the study of Teemu et al. (2004) which argues that to enhance corporate profitability, emphasis should foremost be directed to the most profitable customers and focus on building and nurturing relationships with them. This focus is assumed to yield a better return on the marketing investment and to improve corporate profitability. This means that building relationships with the most profitable customers is moderating the relationship between customer profitability analysis and companies profitability. This is further affirmed by Marc (2000) who argues that measuring customer profitability and understanding the drivers of customer and value can lead to the improvement of overall corporate performance. This emphasizes that customer value moderates the relationship between customer profitability analysis and companies profitability. Moreover, the indirect relationship between customer profitability analysis and companies profitability is also supported by Studies of Noone and Griffin (1997; 1998); Raaij (2005); Krakhmal (2006); and Jasmin (2009) which argue that each dollar of profit generated by the customer does not contribute equally to a company's profitability. The value of the Customer profitability analysis value lies in its ability to improve strategic decision making by providing useful information for customer related decisions, including pricing, discounting and marketing decisions. This means that the relationship between customer profitability analysis and companies profitability is indirect. It can be concluded that the literature review has consistent evidence with regards to the indirect relationship between customer profitability analysis and companies profitability and the use of customer value analysis moderates the relationship between the customer profitability analysis and companies profitability. However, these studies used different variables and different approaches and also did not focus on a comprehensive framework to manage customer value.

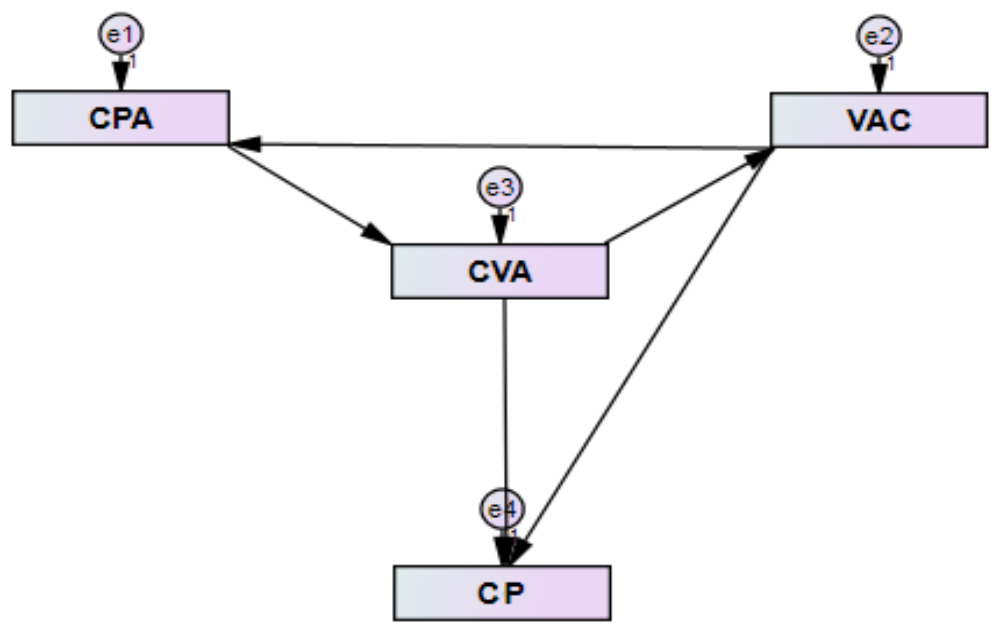

Figure 3. The revised model 


\section{Ml Macrothink}

International Journal of Accounting and Financial Reporting

ISSN 2162-3082 2020, Vol. 10, No. 1

Table 3

\begin{tabular}{lllllll}
\hline $\begin{array}{l}\text { Dependent } \\
\text { variable }\end{array}$ & $\begin{array}{l}\text { Independent } \\
\text { variable }\end{array}$ & Hypothesis & $\begin{array}{l}\text { Direction } \\
\text { of }\end{array}$ & $\mathrm{B}$ & $\mathrm{p}$ & Conclusion \\
\hline $\mathrm{CP}$ & $\mathrm{CPA}$ & $\mathrm{H} 1$ & Removed & - & - & - \\
\hline $\mathrm{CVA}$ & $\mathrm{CPA}$ & $\mathrm{H} 2$ & Positive & .728 & $<0.001$ & Significant \\
\hline VAC & CVA & H3 & Positive & .497 & $<0.001$ & Significant \\
\hline $\mathrm{CP}$ & VAC & H4 & Positive & .391 & $<0.001$ & Significant \\
\hline CPA & VAC & H5 & Positive & .285 & $<0.05$ & Significant \\
\hline CP & CVA & H6 & Positive & .945 & $<0.001$ & Significant \\
\hline & & Research & & & & \\
\hline
\end{tabular}

Recommended

Fit index level of fit model

\begin{tabular}{|c|c|c|}
\hline $\mathrm{x} 2 / \mathrm{df}$ & $\begin{array}{l}\text { Ratio of } \chi \text { to df } \\
\leq 2 \text { or } 3 \text {, useful } \\
\text { for nested } \\
\text { models/model }\end{array}$ & 1.750 \\
\hline RMSEA & $\leq .08$ & .062 \\
\hline RMR & $\begin{array}{l}\text { below } 0.10 \text {, the } \\
\text { better; } 0 \text { indicates } \\
\text { perfect fit }\end{array}$ & .004 \\
\hline CFI & $\begin{array}{lrr}> & .90 & \text { for } \\
\text { acceptance } & \end{array}$ & .999 \\
\hline GFI & $\begin{array}{lrr}> & .90 & \text { for } \\
\text { acceptance } & \end{array}$ & .996 \\
\hline AGFI & $>.80$ & .956 \\
\hline
\end{tabular}


Closer to 1 the

NFI better the fit $\quad .997$

$\geq .95$ can be $0<$

TLI $<1$ for

TLI $\quad$ acceptance $\quad .991$

\begin{tabular}{lll}
\hline & $\geq .95$ & for \\
IFI & acceptance & .999 \\
\hline
\end{tabular}

Table 4

\begin{tabular}{|c|c|c|c|}
\hline & Total Effects & Direct Effects & Indirect Effects \\
\hline $\mathrm{CP}<---\mathrm{VAC}$ & .349 & .349 & - \\
\hline $\mathrm{CP}<---\mathrm{CVA}$ & .858 & .858 & - \\
\hline CVA <-- CPA & .776 & .776 & - \\
\hline VAC <--- CVA & .701 & .701 & - \\
\hline $\mathrm{CPA}<---\mathrm{VAC}$ & .263 & .236 & - \\
\hline $\mathrm{CP}<---\mathrm{CPA}$ & .597 & - & .597 \\
\hline
\end{tabular}

The proposed framework concerns managing customer value using management accounting techniques. This new framework provides management accounting with a new comprehensive tool to identify strategic information about how companies make a profit by focusing on customer value. In addition, such a new framework expands the range of information offered by management accounting and improves the role of management accounting. It allows combining various management accounting techniques that focus on the customer, together. This combination provides management with strategic information to create a competitively superior value which leads to improved profitability. It does so by providing the managers with useful information about the profitable customers that companies should be focused on using customer profitability analysis technique. It also provides managers with information to a better understanding of which activities and outcomes actually create value for profitable customers using customer value analysis technique. Moreover, it provides managers with information about the cost of the core value activities using value costing technique. Such information helps managers to effectively manage the cost of the core value activities and hence boost customer profitability and the company's profitability. Taken together the three techniques with the proposed sequences form a framework that provides deeper insight into managing customer value and enhancing 
companies' profitability from the management Accounting perspective.

Successful implementation of the proposed framework in the service sector requires a multi-functional team, where management accountants work closely with marketing, operations management, product development, and general management employees.

\section{Conclusion}

This study develops a conceptual management accounting framework to manage customer value.

It is based on using together three proposed techniques with the following sequences: customer profitability analysis; customer value analysis; and value-added costing. This framework aims to provide the managers with useful information about the profitable customers that companies should be focused on. It also provides managers with information to a better understanding of which activities and outcomes actually create value for profitable customers. Moreover, it provides managers with information about the cost of the core value activities. Such information helps managers to effectively manage the cost of the core value activities and hence boost customer profitability. Taken together the three techniques with the proposed sequences form a framework that provides deeper insight into managing customer value and enhancing companies' profitability from the management Accounting perspective.

This paper makes a number of distinguished contributions to the management accounting literature. The major contribution of this paper is the proposition of a new comprehensive framework for managing customer value using management accounting techniques. This framework focuses on using together with the three proposed techniques with the proposed sequences to manage customer value, which has not been addressed in the existing literature. This comprehensive framework creates a new database that can be used in boosting the company profitability, which also has not been discussed in the existing studies.

The study was conducted in the Egyptian service sector and provides specific information of value in this specific sector, not addressed in the existing literature. A key result of the quantitative analysis was that there is an indirect relationship between customer profitability analysis and companies profitability which not empirically examined in the literature. A significant finding in the revised model indicated that there is a direct relationship between customer value analysis and companies profitability which also has not been empirically investigating in the existing literature.

As with any study, there are limitations. As this study was conducted only in a single country and in a single sector, that of the Egyptian service sector. The findings of this study are influenced by the particular nature and characteristics of the service sector. Therefore, the generalization of findings beyond the Egyptian service sector should be made with caution. Another limitation is that the use of judgment sampling in the current study may increase the risk of producing bias and inefficient parameter estimates, which should be taken into consideration (Guo and Hussey, 2004).

The current study found that the proposed framework affected companies' profitability. 
However, further examination of the influence of such framework on the competitive advantage is an interesting area for future research.

\section{References}

Abeer, M. (2017). The Use of Customer Value-Driven Cost Management Technique to Increase the Profit Potential Opportunities - A Proposed Comprehensive Framework. International Journal of Applied Business and Economic Research, 15(10), 169-189.

Al-Nashar, T. (2001). A Proposed Framework for Integrating Process Based Costing and Attribute Based Costing Techniques. Journal of Faculty of Commerce for Scientific Research, 2, 20-70.

Anonymous, A. (2018). Egypt - Economic sectors. Retrieved January 2018, from http://www.nationsencyclopedia.com/economies/Africa/Egypt-ECONOMIC-SECTORS.html

Anonymous, B. (2018). Service companies listed in EEM. Retrieved January 2018, from http://www.egx.com.eg/English/ListedStocks.aspx

Brewton, J., \& Schiemann, W. (2003). Measurement: the Missing Ingredient into Day's CRM Strategies. Journal of Cost Management, 17(1), 5-14.

Brimson, J. (1998, January/February). Feature Costing Beyond ABC. Journal of Cost Management, 6-12.

Bromwich, M. (1988). Managerial Accounting Definition and Scope - From a Managerial View. Management Accounting, 66(8), 26-27.

Byrne, B. (1998). Structural Equation Modelling with LISREL, PRELIS, and SIMPLIS: Basic Concepts, Applications, and Programming. Lawrence Erlbaum Associates, Mahwah, NJ.

Chin, W., \& Todd, P. (1995). On the use, usefulness, and ease of structural equation modelling in MIS research: a note of caution. MIS Quarterly, 19(2), 237-46.

Cokins, G. (2006, February). Measuring Customer Value: How BPM Supports Better Marketing Decisions. Business Performance Management, 13-18.

Cooper, R., \& Kaplan, R. (1991). Profit priorities from activity-based costing. Harvard Business Review, 69(3), 130-5.

Cotton, B. (2005, April). Relevance redux - management accounting today. Chartered Accountants Journal, 6-12.

Day, G. (1994). The Capabilities of Market-Driven Organizations. Journal of Marketing, 58(4), 37-52.

Erik, M., \& Raaij, V. (2005). The strategic value of customer profitability analysis. Marketing Intelligence \& Planning, 23(4), 372-381.

Gabre, M. (2007). Strategic Management: A New Approach. Cairo: Dar Almarref.

Gale, B. (1994). Managing Customer Value: Creating Quality and Service That Customers 
Can See. New York: A Division of Simon\& Schuster Inc.

Gale, B. (2000). Trends in Customer Satisfaction, Loyalty, and Value. Retrieved October 20, 2018, from www.mria-arim.ca/montreal/pdf/DrGalpaper

Gary, C. (2015, February). Measuring and Managing Customer Profitability. Strategic Finance, 23-29.

Guo, S., \& Hussey, D. (2004). Non-Probability Sampling in Social Work Research: Dilemmas, Consequences, and Strategies. Journal of Social Service Research, 30(3), 1-18.

Hair, J., Black, W., Babin, B., Anderson, R., \& Tatham, R. (2006). Multivariate Data Analysis. Pearson Education, Upper Saddle River, NJ.

Hair, J., Money, A., \& Samouel, P. (2007). Research Methods for Business. West Sussex: Johan Wiley\& Sons.

Horngren, C., Bhimani, A., Dater, S., \& Foster, G. (2005). Management and Cost Accounting (3rd ed.). New Jersy Prentice Hall.

Horngren, C., Dater, S., \& Foster, G. (2006). Cost Accounting: A Managerial Emphasis (10th ed.). New Jersey USA: Prentice Hall.

Howell, Robert, A., \& Soucy, S. (1990). Customer Profitability - As Critical as Product Profitability. Management Accounting, 72(4).

Howes, K. (2003). Customer Value Management and Development in Europe. Retrieved August 15, 2018, from www.edgardunn.com

Howitt, D., \& Cramer, D. (2008). Introduction to SPSS in Psychology for Version16 and Earlier (4th ed.). Pearson Education, Essex.

Hu, L., \& Bentler, P. (1995). Structural Equation Modelling: Concepts, Issues, and Applications. Sage, Thousand Oaks, CA.

Ilhan, D., Tanis, V., \& Kosan, L. (2010). Customer profitability analysis with time-driven activity-based costing: a case study in a hotel. International Journal of Contemporary Hospitality Management, 22(5), 609-637.

Jasmin H., (2009). Customer profitability analysis. Technical Information Service, CIMA. Series No. 55, 1-11

Jensen, M. (2001). Value Maximization, Stakeholder Theory, and the Corporate Objective Function. Journal of Applied Corporate Finance, 14(3), 7-21.

Kaplan, R., \& Narayanan, V. (2001), Customer Profitability Measurement and Management. Working Paper, Harvard Business School.

Keith, T. (2006). Multiple Regression and Beyond. Pearson, Boston, MA.

Kline, R. (2005). Principles and Practice of Structural Equation Modelling (2nd ed.). The Guilford Press, New York, NY. 


\section{Macrothink}

International Journal of Accounting and Financial Reporting ISSN 2162-3082

Krakhmal, V. (2006). Customer profitability in the context of hotels. In Harris, P. J. \& Mongiello, M. (Eds.), Accounting and Financial Management: Developments in the International Hospitality Industry (pp. 188-210).

Marc, J. (2000). Customer Profitability Analysis (pp. 1-32). The Society of Management Accountants of Canada, the American Institute of Certified Public Accountants and the Chartered Institute of Management Accountants.

McNair, C. J. (2007). Beyond the boundaries: future trends in cost management. Cost Management, 21(1), 10-21.

McNair, C., \& Polutnik, L. (2001). Closing the cost-value gap. Journal of Cost Management, 15(2), 5-11.

McNair, C., Polutnik, L., \& Silvi, R. (2001a). Cost Management and Value Creation: the Missing Link. The European Accounting Review, 10(1), 33-50.

McNair, C., Polutnik, L., \& Silvi, R. (2001b). Customer Value: A New Kind of Cost Management. The Journal of Corporate Accounting \& Finance, 12(3), 9-14.

McNair, C., Polutnik, L., \& Silvi, R. (2006, November/December). Customer-Driven Lean Cost Management. Cost Management, 9-21.

McNair, C., Polutnik, L., Silvi, R, \& Watts. (2013, November/December). Putting the Customer First: Value- based Cost Management. Cost Management, 6-17.

Morse, W., Davis, J., \& Harlgraves, A. (2003). Management Accounting a Strategic Approach. South Western: Thomson.

Noone, B., \& Griffin, P. (1997). Enhancing yield Management with Customer Profitability Analysis. International Journal of Contemporary Hospitality Management, 9(2), 75-79.

Noone, B., \& Griffin, P. (1998). Development an Activity Based Customer Profitability System for Yield Management. Progress Tourism and Hospitality Research, 4, 279-292.

Pickering, M. (1998). Customer profitability: The approach counts. Charter, 69(6), 32-35.

Raaij, E. (2005). The Strategic Value of Customer Profitability Analysis. Marketing Intelligence \& Planning, 23(4/5), 372-381.

Raaij, V. E. M., Vernooij, M. J. A., \& Triest, S. V. (2003). The Implementation of customer profitability analysis: a case study. Industrial Marketing Management, 32(7), 573-83.

Reinaldo, G., Rodrigues, S., Elvira, B., \& Villamor, V. (2008). Cost-to-serve Measurement and customer profitability analysis. The International Journal of Logistics Management, 19(3), 389-407.

Salem, A. (2002). How to Manage Customer - A Case Study. The Scientific Journal of Commerce and Finance, 2, 310-340.

Smith, M., \& Dikolli, S. (1995). Customer Profitability Analysis: An Activity Based Costing 


\section{Macrothink \\ International Journal of Accounting and Financial Reporting \\ ISSN 2162-3082 2020, Vol. 10, No. 1}

Approach. Managerial Auditing Journal, 10(7), 3-7.

Sullivan, U., Peterson, R., \& Krishnan, V. (2012). Value creation and firm sales performance: The mediating roles of strategic account management and relationship perception. Industrial Marketing Management, 41(1), 166-173.

Tabachnick, B., \& Fidell, L. (2001). Using Multivariate Statistics (4th ed.). Allyn and Bacon, Boston, MA.

Teemu, M., Mika, R., Siegfried, G., \& Jussi, S. (2004). An empirical study on customer profitability accounting, customer orientation and business unit performance. The EAA conference in Praque (pp. 1-30).

Tomczyk, P., Doligalski, T., \& Zaborek, P. (2016). Does customer analysis affect firm performance? Quantitative evidence from the Polish insurance market. Journal of Business Research, 69(9), 3652-3658.

Valenzuela Fernández, L. M., \& Torres, E. (2017). Does Customer Value-oriented Management Influence Financial Results? A Supplier's Perspective. Innovare, 27(63), 29-42.

Velicer, W., \& Fava, J. (1998). Effects of variable and subject sampling on factor pattern recovery. Psychological Methods, 3(2) 231-251.

Walker, M. (1992). Attribute Based Costing. Australian Accountant, 62(2), 42-45.

Walker, M. (1998). Attributes or activities? Looking to ABCII. Australian CPA, 68(9), 26-28.

Walker, M. (1999). Attribute based costing: For decision making. Management Accounting, 77(6), 18-22.

Woodruff, R. (1997). Customer value: The next source for competitive advantage. Academy of Marketing Science Journal, 25(2), 139-153.

Zeithaml, V., \& Bitner, M. (1996). Service Marketing. McGraw-Hill- US.

Zeithaml, V., Rust, R., \& Lemon, K. (2001). The customer pyramid: creating and serving profitable customers. California Management Review, 43(4), 118-44.

\section{Copyright Disclaimer}

Copyright for this article is retained by the author(s), with first publication rights granted to the journal.

This is an open-access article distributed under the terms and conditions of the Creative Commons Attribution license (http://creativecommons.org/licenses/by/4.0/) 